\title{
Sciendo
}

RURAL SUSTAINABILITY RESEARCH 45 (340), 2021

ISSN - 2256-0939

(c) Latvia University of Life Sciences and Technologies, all rights reserved http://www.llu.Iv/en/

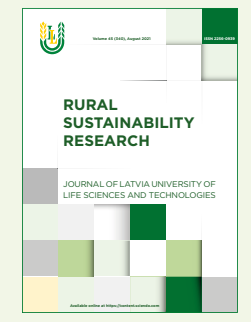

Received: 2 February 2021

Revised: 23 March 2021

Accepted: 7 April 2021

\section{Project Valuation and Risk Assessment in Food Product Development: Evidence from Fuzzy Real Option Valuation}

\author{
*Irina Pilvere ${ }^{1}$, Mihails Silovs ${ }^{1}$, Janis Ozolins $^{2}$, Aleksejs Nipers ${ }^{1}$, Olga Dmitrijeva $^{1}$ \\ ${ }^{1}$ Latvia University of Life Sciences and Technologies, Liela street 2, Jelgava, Latvia \\ ${ }^{2}$ Corporate Management Experts Bureau Ltd, Baznicas street 13-17, Riga, Latvia
}

\begin{abstract}
To survive in today's competitive environment, companies must continuously develop and offer customers new products. To increase the probability of a successful business case of investing in the development of a new product, careful attention must be paid to risk analysis in terms of the present value of future potential income. The article considers an example of the research work of the Latvia University of Life Sciences and Technologies, in the framework of which a technical and technological project was developed to produce a new product, like Mediterranean anchovy, from cheaper Baltic sprats. The main goal of this work is to explore the application multi-factor sensitivity and fuzzy real option analysis to the valuation of new product development project.

The multivariate analysis of the sensitivity of the financial model of the greenfield production project described in this article revealed the main risk groups, as well as their degree of influence on the assessment of the Net Present Value of the project by a potential investor. The use of Fuzzy Real Option Valuation made it possible to evaluate the project with uncertain parameters, as well as to calculate the potential upside from preliminary refinement of parameters to eliminate negative scenarios.

The described approach is applicable to risk assessment of new food product development and allows investors to make a more informed decision about participation in such projects.
\end{abstract}

Keywords: new products, project valuation, sensitivity and real option analysis, uncertainty, fuzzy numbers.

\section{Introduction}

As part of the Research\&Development (R\&D) project, the Latvia University of Life Sciences and Technologies developed a technical and technological project for the production of a new product, similar to the Mediterranean anchovy, from cheaper fish, called Baltic sprats (Sprattus sprattus balticus) (Sabovics et al., 2019a).

The limited demand for traditional canned smoked products (sprats in oil) generates the need to expand the range of fish food products made from the traditionally available Latvian raw materials - Baltic sprat (Sabovics et al., 2019b). In the same time, being one of the most expensive fish products, anchovies in oil have an extremely high added value (PerezVillarreal \& Pozo, 1992).
After extensive research, the scientists from Faculty of Food Technology of the Latvia University of Life Sciences and Technologies have successfully created the necessary product, which is very similar to the Mediterranean counterpart by the organoleptic characteristics. Also, as part of the research work, a detailed investment project was compiled by involved economists, accessible for investors willing to start production of this product. This study extends the compiled investment project and offers framework for potential risk assessment that can be used in similar projects.

The main goal of this research is to explore the application multi-factor sensitivity and fuzzy real option analysis to the valuation of new product development project.

\footnotetext{
* Corresponding Author's email: Irina.Pilvere@1lu.lv
} 


\section{Materials and Methods}

Using an example of an innovative project to produce Mediterranean salted anchovies from Baltic sprats, authors will analyze the Discounted Cashflow of the project to obtain a nominal Net present value (NPV). Next, a sensitivity analysis will be carried out, which will show the main risks of the project.

Finally, real option models will be explored, focusing on their use of fuzzy numbers to capture the value of real options under the presence of uncertainty. A fuzzy NPV(FNPV) will be computed, which will include the ability (option) to postpone the project, to clarify the parameters and the ability to abandon the project if NPV becomes negative with the clarified parameters.

The analysis continues in the literature review, which analyzes the related scientific literature on risks associated with the development of new products, sensitivity analysis in evaluating a project, and working with fuzzy sets. The next part, examines the use of the above mentioned tools on a specific example of new product development (NPD), and finally, the last part presents the findings of the study.

\section{LITERATURE REVIEW}

New Product Development (NPD) Risks

NPD is a process of transforming ideas into innovative products to move them to the market. It is linked to taking and managing risks, as most activities can be viewed as a constant reduction of uncertainty. Preliminary studies of customer needs and market trends can reduce the uncertainty of the requirements to develop new products. This will ensure certainty company's capabilities over technology development, testing, and evaluation when undergoing the NPD process (Mu, Peng, \& MacLachlan, 2009). Reducing risks in new product development shall be used to analyze and adjust product development processes. Findings by R.K.Moenaert et al. (1995) state that uncertainty reduction throughout the new product development augments the likelihood of the success of commercializing a new product. The authors agree on the reduction of market uncertainty to make sure the exploitation of the latest merchandise. Y.J.Kim and N.S.Vonortas (2014) adapted four main domain usually used in NPD that is market, technology, operational, and financial to study how enterprises mitigate and manage risks. They chose the risk domain from J.A.Keizera, J.I. M.Halman, \& M. Song (2002) risk management diagnostic method used in developing new products. The research by J.A.Keizera, J.I. M., Halman \& M. Song (2002) shows evidence of strategic actions in handling risk. Evidence found that companies would extensively use internal risk management strategies in an unstable environment. The following risks that affect NPD performance are shown in Table 1.

Technological risk involves a firm's inability to understand or predict aspects of technological environment related to NPD projects (Milliken, 1987). The source of such risk can come either from inside or outside of an organization. The higher the complexity of the technological environment, the higher the technology risk is. Although firms might not foresee the rise of new technology or predict when technology becomes obsolete (Freeman \& Soete, 1997), researchers suggest many strategies of risk mitigation. M.H.Meyer and E.B.Roberts (1986) recommend an approach to implement only one growth-maintaining technology to avoid high levels of diversification in NPD. Y.J.Kim and N.S.Vonortas (2014) suggest that companies need to continuously improve their products frequently by maintaining regular in-house research activities to mitigate technological risks.

Market risk refers to uncertainty about customer

Table 1

Risks Affecting the NPD Success

\begin{tabular}{|l|l|}
\hline Types of Risks & Risk description \\
\hline Technology Risk & $\begin{array}{l}\text { Not completely understand or predict technology environment, lack of technical } \\
\text { capabilities. }\end{array}$ \\
\hline Market Risk & Product does not meet with needs or expectation, customer changing needs. \\
\hline Organizational Risk & $\begin{array}{l}\text { Competition among companies on resources, human resource availability, supply } \\
\text { chain changes. }\end{array}$ \\
\hline Financial Risk & Lack of financial capability to undertake NPD, lack of working capital. \\
\hline
\end{tabular}

Source: authors created based on (Mansor, Yahaya, \& Okazaki, 2016). 
needs that can be satisfied by a technology or developed product. A lot of the existing research evidence suggests that the failure of NPD may mainly be due to improper marketing. Unlike technology risk, market risk is the least controllable risk factor in NPD as it is external to firms (Park, 2010). Nonetheless, studies have found that reliable knowledge about client preferences is the most important type of information for product development (Cooper \& Kleinschmidt, 1995). Other research suggests the pre-testing the pilot batches of a product may reduce the market risks (Moskowitz, Saguy, \& Straus, 2009).

Limitations on internal resources can also become essential for firms at the beginning of NPD projects. It increases uncertainties and risks when companies decide to compete for scarce resources (Anderson \& Tushman, 2001). Moreover, in order to reduce organizational risks, firms can learn best practices and share knowledge and capabilities since external networks showed to foster innovation (Ahuja, 2000). Literature dealing with small firms, focuses on external relations, covering such issues as industrial subcontracting, licensing, networking, and shared R\&D (Dodgson \& Rothwell, 1991).

Financial risks are often vital for smaller companies willing to innovate with limited access to financial resources (Jerrard \& Hands, 2007). Nonetheless, in the current study, authors assume that potential investor has access to necessary finance, and the realization of the project in question is not subject to this specific risk.

\section{NPV}

There is a lot of investment analyses methods available, yet the net present value (NPV) analysis, based on the discounted cash flow, is one of the most commonly used due to its easy applicability and wellknown methodology (Sari \& Kuchta, 2012).

NPV of a project is calculated by adding up of present values of all positive and negative cash flows of the project. Present value of future payment PV (F) after $\mathrm{n}$ years from now is calculated as:

$$
P V(F)=F \frac{1}{(1+r)^{n}}
$$

Where $\mathrm{F}$ is the amount of the payment and $\mathrm{r}$ is the compound interest rate.

NPV of a cash flow series with equal payments on each time period is calculated as follows:

$$
N P V(A, I)=-I+\sum_{j=0}^{n} \frac{A j}{(1+r)^{j}}
$$

With A being the amount of annual payment, $n$ being the time period of the payments and I, being the investment of the project.

The formula for the NPV of a cash flow series (NPV $\left.\left(\mathrm{F}_{1}, \ldots \mathrm{F}_{\mathrm{m}}\right)\right)$ with $\mathrm{m}$ different payments is:
$N P V\left(I, F_{1} . . F_{m}\right)=-I+\left(F_{1} \frac{1}{(1+r)^{n_{1}}}\right)+\cdots+\left(F_{m} \frac{1}{(1+r)^{n_{m}}}\right)(3)$

Where $F_{m}$ being the amount of the payment and $n_{m}$ being the time-period of the payment.

By such a formulation of NPV, it is easier to calculate the PV when the discount rates are different for different periods.

\section{Sensitivity analysis}

Sensitivity analysis is a vital technique for defining the effects of factor changes on the model. It helps to find out which financial model parameters have a more significant influence on the output of the model. Notably, in risky environments, the robustness of the model is determined by sensitivity analysis. R.B.Taylor and T.M.West (1992) designed the sensitivity evaluation model used to assist investment decisions with multiple parameters designed. P.Jovanovic (1999) summarized the methods applied in investment analysis under uncertainty and on an example of investment decision making procedure used sensitivity analysis. W.J.H.Van Groenendaal and J.P.C.Kleijnen (2002) compared two methods of sensitivity analysis to find out which factors are essential in investment decision making. E.Borgonovo and L.Peccati $(2004 ; 2006)$ discussed the importance of different measures and their relation to local sensitivity analysis techniques applied to the discounted cash flow valuation. They used sensitivity analysis as a tool to undertake the investment decisions and proposed ways to determine key factors in NPV and internal rate of return (IRR) of an investment. H.E.Klingelhöfer (2009) used sensitivity analyses and proposed an approach to evaluating investments and showed that tradable permits do not always encourage environmentally beneficial investments. Sensitivity analysis has been used on real option valuation to understand the importance of the key parameters (Haahtela, 2010). J.N.Sheen (2005) computed FNPV and payback models by using sensitivity analysis to gain more information on uncertain data.

In more practical terms, if, for example, a decision maker is choosing between accepting or rejecting the project due to its net present value and has the option of changing some of the cash flows by altering materials used, clients, suppliers or machinery, he prefers to find out the portion of the cash flow coming from different parameters of project NPV. If factors of the cash flow are determined as $\mathrm{F}_{1} \ldots \mathrm{F}_{\mathrm{m}}$, the present values of the factors $\mathrm{PV}^{\mathrm{k}}$ could be calculated:

$$
P V^{k}=\sum_{j=q}^{n} \frac{F_{j k}}{(1+r)^{n_{j}}}
$$

It shall be noted that NPV of the project is equal to the sum of the NPVs of the factors where PVI is the 
present value of the initial investment.

$$
\mathrm{NPV}=-\mathrm{PV}^{\mathrm{I}}+\mathrm{PV}^{1}+\cdots+\mathrm{PV}^{\mathrm{k}}
$$

Sensitivity analysis can be "local" or "global". Local sensitivity analysis is the sensitivity of the model result at the change of only one input parameter at a time while all other input parameters being at their base values. Global sensitivity found out the effect on model result of the change of all the factors in the same time over their ranges of uncertainty (Haaker \& Verheijen, 2004).

\section{Fuzzy numbers}

The boundary between the products that should be accepted and those to be rejected is never quite clear (also if crisp NPV is used) (Kahraman, 2008). In an uncertain decision-making environment, information on cash flows, capital expense, interest rate, cost of capital, etc. is often vague (Kahraman, Ruan, \& Tolga, 2002). That is why this study proposes the fuzzy binomial valuation approach to evaluate investment projects in uncertain decision-making environments.

The fuzzy set theory was founded by L.A.Zadeh (1965). A fuzzy set is a class of objects with a continuum of grades of membership, characterized by a membership function that attributes to each object a grade of membership ranging between zero and one.

A fuzzy set $A$ in $U$ is characterized by a membership function $\mu \mathrm{A}(\mathrm{x})$ which associates with each point in $\mathrm{U}$ a real number from $[0,1]$, with the value of $\mu \mathrm{A}$ (x) and representing the grade of membership of $\mathrm{x}$ in A (Zadeh, 1965).

Flexibility to adopt future actions by the management introduces an asymmetry in the probability distribution of the project NPV (Yeo \& Qiu, 2003). Without such flexibility, the probability distribution of project NPV would be symmetric. Nevertheless, with the managerial flexibility to, for example, exercise the options, extra upside potential is introduced and the distribution is inclined to the right (Ho \& Liao, 2011).

As stated before, projects are treated as independent investment opportunities, and decisions are often made to accept projects with positive NPVs. Nonetheless, traditional NPV techniques ignore future flexibilities of the factors; therefore, they may undervalue the projects and mislead the decision-makers.

As market conditions or the understanding of base case parameters might change in the future, investment projects may include choices by which project value can be raised. Such choices are called real options or strategic options. The real option project valuation approach seeks to correct the shortages of the traditional valuation methods by recognizing that managerial choices can bring significant value to projects.

S.Muzzioli and C.Torricelli (2004) modeled the stock price as a fuzzy number, and a possibility distribution of probability in a multi-period binomial model was obtained. That allowed us to compute the option price with an expected value interval, which allowed us to determine the "most likely" option value within the interval. S.Muzzioli and H.Reynaerts (2008) used a possibility distribution to model volatility uncertainty and to price an American option in a multi-period binomial model.

Ch.Carlsson et al. (2007) introduced a real option rule in a fuzzy setting in which the NPVs of expected cash flows are estimated by trapezoidal fuzzy numbers. They developed a methodology for valuing options in development projects, in which future cash flows were also estimated by trapezoidal fuzzy numbers.

J.C.Cox, S.A. Ross and M.Rubinstein (1979) developed binomial option valuation technique that has become widespread option due to its intuitive nature and broad applicability to variety of option attributes. The valuation approach used in the current study is based on C.Cox, S.A. Ross and M.Rubinstein (1979) and Sh.H.Ho and Sh.H.Liao (2011) is outlined below.

\section{Binomial valuation of fuzzy NPV with options}

Let us assume there is an asset with a PV of $\mathrm{S}_{0}$. Its value has a probability of $\mathrm{P}_{\mathrm{u}}$ to go up to $\mathrm{uS}_{0}$ or $\mathrm{P}_{\mathrm{d}}$ to go down to $\mathrm{dS}_{0}$. Factors $\mathrm{u}$ and $\mathrm{d}$ represent the coefficients by which the PV of the asset may change up or down, respectively. Let us assume, there is an option for such an asset with an exercising price of K. If the value of the asset is higher than $\mathrm{K}$, the option will be exercised, and if the value is lower than $\mathrm{K}$, it will be dropped.

Option sell price $\mathrm{C}_{0}$, can be determined by the following expression:

$$
C_{0}=\frac{1}{(1+r)}\left[P_{u} C_{1 u}+P_{d} C_{1 d}\right]
$$

in which $\mathrm{r}$ is the risk-free interest rate, and $\mathrm{P}_{\mathrm{u}}$ and $\mathrm{P}_{\mathrm{d}}$ are probabilities.

As discussed above, and due to overall uncertainty accompanying any valuation of the future, this study considers possibility uncertainty rather than probabilistic uncertainty and employs fuzzy numbers instead of statistics to estimate the parameters. Authors utilize the triangular fuzzy numbers $u=\left[u_{1}, u_{2}, u_{3}\right]$ and $d=\left[d_{1}, d_{2}, d_{3}\right]$ to represent the jumping factors of the underlying asset. As a result, option values $\mathrm{C}_{1 \mathrm{u}}$ and $\mathrm{C}_{1 \mathrm{~d}}$ become fuzzy numbers as a result of the jumping factors being fuzzified. That is, $C_{1 u}=\max \left(\tilde{u} S_{0}-K, 0\right)$ and $C_{1 d}=\max \left(d S_{0}-K, 0\right)$, which basically means that it will be greater than 0 if in any possible scenarios the value $\mathrm{S}$ becomes bigger than 0 .

Thus, in general form the pricing formula for the 
fuzzy call option is:

$$
\tilde{C}_{0}=\frac{1}{1+r}\left[\tilde{P}_{d} \otimes \tilde{C}_{1 d} \oplus \tilde{P}_{u} \otimes \tilde{C}_{1 u}\right]
$$

In a practical sense, the NPV of the project is its current value. The price of the option is the current value of a potential change in the value of the project due to the positive deviation of the initially modeled parameters due, for example, to the actions of the project management. Using fuzzy digits to determine NPV, the distribution of a possible project NPVs is skewed to the right. In this study, we use the method proposed by Sh.H.Ho and Sh.H.Liao (2011) of obtaining the mean FNPV (Figure 1).

$$
E(F N P V)=\frac{(1-\lambda) c_{1}+c_{2}+\lambda c_{3}}{2}
$$

Where $\lambda=\frac{A_{r}}{A_{L}+A_{r}}$ and $\lambda=\frac{c_{3}-c_{2}}{c_{3}-c_{1}}$

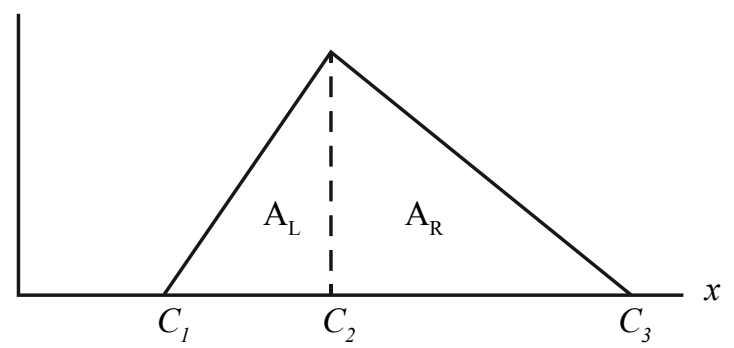

Source: authors created based on Ho \& Liao, 2011

Figure 1. FNPV distribution.

\section{Results and Discussion}

As part of the research work of the Latvian University of Life Sciences and Technologies, a technical and technological project was developed to produce a new product similar to Mediterranean anchovy from cheaper Baltic sprats.
An extensive financial model was developed that considers various parameters and based on them builds the probable cash flow of a potential project. The financial model of the project was developed to present this project to potential investors. The authors determined the set of parameters for modeling. Leaving the justification for choosing the base values of specific parameters outside the scope of this study, we only note that all parameters correlate with empirically defined risks defined in the theoretical part (Table 2).

$N P V$

At the first stage of financial analysis, NPV was chosen as the primary indicator of the project's attractiveness. The choice of this indicator is straightforward and goes in line with the economic theory. To calculate NPV, authors used the approach stated before. The cash flow was taken from the developed financial model, and a discount rate is assumed to be of 5\% per year (authors will leave its justification outside the scope of this study). A highly simplified financial model is shown in project cashflow (Table 3).

After conducting an initial analysis of the financial model, we received an NPV of the project of 58563 thousand EUR, which indicates the theoretical present value of the project; however, it is entirely based on the assumption made by authors about the project parameters and does not consider any uncertainty.

Sensitivity analysis

To expand the investor's understanding of the possible risks of the project, at the second stage of the analysis, we asked the experts to evaluate the potential annual fluctuations of the initially adopted project parameters (Table 4).

Table 2

Consumption of the coating products on the surface of the samples

\begin{tabular}{|l|l|}
\hline Factors & Nature of risk \\
\hline Sales volume & Market risk - bad marketing, small bargaining power. \\
\hline Proportion Anchovies to Pasta & $\begin{array}{l}\text { Organizational/technological risk - inability to satisfy the production due to } \\
\text { incorrect redistribution of raw material (which is the same for two products). }\end{array}$ \\
\cline { 1 - 1 } Anchovies in oil, sales price & $\begin{array}{l}\text { Market/technological risk - bad marketing, small bargaining power, } \\
\text { inability to satisfy market price due to technological limitations. }\end{array}$ \\
\cline { 1 - 1 } Anchovy pasta, sales price & $\begin{array}{l}\text { Technological/organizational - costly technology, raw material price } \\
\text { fluctuation, lack of finance to assure long term contracts. }\end{array}$ \\
\cline { 1 - 2 } Olive oil expense & \\
\cline { 1 - 2 } Labor costs &
\end{tabular}

Source: authors created. 
Simplified Project Cashflow, EUR

\begin{tabular}{|l|c|c|c|c|}
\hline Position\Period in years & 0 & 1 & $\ldots$ & 9 \\
\hline Cashflow from operations & 0 & 162174 & 162174 & 162174 \\
\hline Capital expense & -1094140 & 0 & 0 & 0 \\
\hline Total & -1094140 & 162174 & 162174 & 162174 \\
\hline
\end{tabular}

Source: authors calculations.

Parameter Deviation from the Base Case, \%

\begin{tabular}{|l|c|}
\hline Parameters & Deviation from base case \\
\hline Sales volume, tons & $+/-10 \%$ \\
\hline Proportion Anchovies to Pasta, $\%$ & $+/-10 \%$ \\
\hline Anchovies in oil, sales price, EUR per ton & $+/-5 \%$ \\
\hline Anchovy pasta, sales price, EUR per ton & $+/-5 \%$ \\
\hline Sprat (raw material) expence, EUR per ton & $+20 \% /-10 \%$ \\
\hline Olive oil expense, EUR per ton & $+/-15 \%$ \\
\hline Labor costs, EUR per hour & $+/-20 \%$ \\
\hline
\end{tabular}

Source: authors calculations.

Sales volume, tonnes 18.35

Proportion Anchovies to Pasta Anchovies in oil, sales price EUR

Labor costs EUR

Anchovy pasta, sales price EUR

Olive oil expense EUR

Sprat (raw material) expense EUR
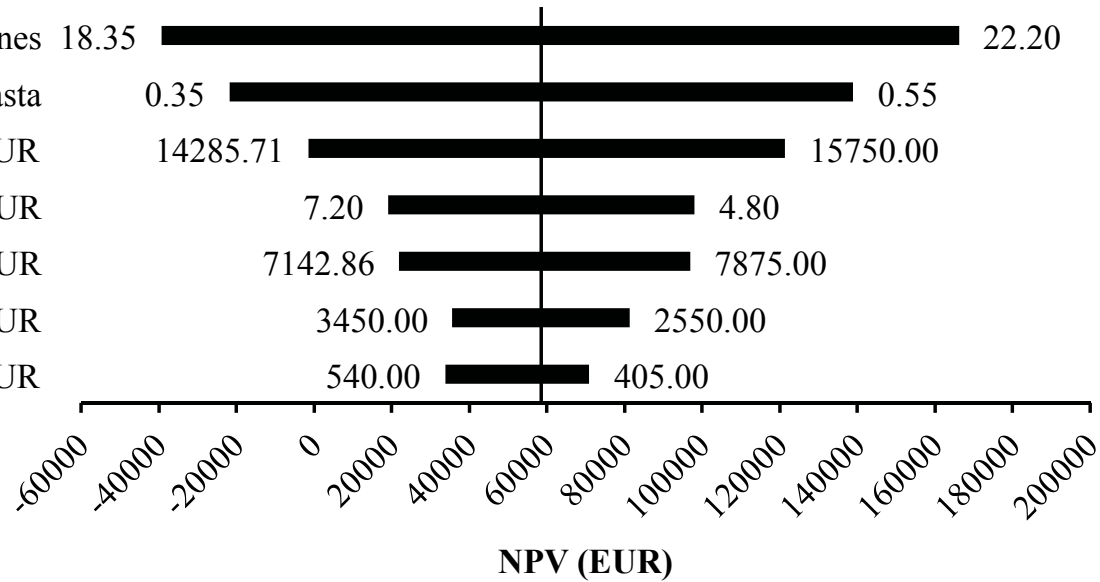

Source: authors calculations.

Figure 2. Local Sensitivity Analysis Results. 
Based on economic theory, sensitivity analysis was carried out of the project NPV, first to a change in one factor, all other things being equal (local analysis), then to a change in two factors (pairwise-local analysis), and in the end, the boundaries of the change in NPV with extreme change in all factors (global sensitivity analysis) was computed.

The results are shown in the Figure 2 to the study in the tables for both local sensitivity analysis. First, they show that possible (allowed by researchers) parameter fluctuations can significantly change the NPV of the project for the investor. At the extreme cases, NPV of the project changes from -264 707 EUR (negative extreme parameters) to 465670 EUR (positive extreme parameters).

Table 5

\begin{tabular}{|c|c|c|c|c|c|c|c|}
\hline \multirow[b]{2}{*}{ Input Variables } & \multicolumn{3}{|c|}{ Corresponding input values } & \multicolumn{4}{|c|}{ NPV output value, EUR } \\
\hline & $\begin{array}{l}\text { Low } \\
\text { output }\end{array}$ & $\begin{array}{l}\text { Base } \\
\text { case }\end{array}$ & $\begin{array}{l}\text { High } \\
\text { output }\end{array}$ & Low & Base & High & Swing \\
\hline $\begin{array}{l}\text { Sales volume, tons \& Proportion } \\
\text { Anchovies to Pasta, \% }\end{array}$ & $\begin{array}{l}18.34 \& \\
35 \%\end{array}$ & $\begin{array}{c}20.18 \& \\
45 \%\end{array}$ & $\begin{array}{c}22.20 \& \\
55 \%\end{array}$ & -112344 & 58563 & 254594 & 366938 \\
\hline $\begin{array}{l}\text { Sales volume, tons \& Anchovies } \\
\text { in oil, sales price, EUR }\end{array}$ & $\begin{array}{c}18.34 \& \\
14285.71\end{array}$ & $\begin{array}{c}20.18 \& \\
15000\end{array}$ & $\begin{array}{c}22.20 \& \\
15750\end{array}$ & -93756 & 58563 & 235398 & 329154 \\
\hline $\begin{array}{l}\text { Sales volume, tons \& Labor costs, } \\
\text { EUR }\end{array}$ & $\begin{array}{c}18.34 \& \\
7.2\end{array}$ & $\begin{array}{c}20.18 \& \\
6\end{array}$ & $\begin{array}{l}22.20 \& \\
4.8\end{array}$ & -75195 & 58563 & 209644 & 284838 \\
\hline $\begin{array}{l}\text { Proportion Anchovies to Pasta, \% } \\
\& \text { Anchovies in oil, sales price, } \\
\text { EUR }\end{array}$ & $\begin{array}{c}35 \% \& \\
14285.71\end{array}$ & $\begin{array}{c}45 \% \& \\
15000\end{array}$ & $\begin{array}{c}55 \% \& \\
15750\end{array}$ & -68363 & 58563 & 215768 & 284131 \\
\hline $\begin{array}{l}\text { Sales volume, tons \& Anchovy } \\
\text { pasta, sales price, EUR }\end{array}$ & $\begin{array}{c}18.34 \& \\
7142.857\end{array}$ & $\begin{array}{l}20.18 \& \\
7500\end{array}$ & $\begin{array}{c}22.20 \& \\
7875\end{array}$ & -72582 & 58563 & 208495 & 281077 \\
\hline $\begin{array}{l}\text { Sales volume, tons \& Olive oil } \\
\text { expense, EUR }\end{array}$ & $\begin{array}{c}18.34 \& \\
3450\end{array}$ & $\begin{array}{l}20.18 \& \\
3000\end{array}$ & $\begin{array}{c}22.20 \& \\
2550\end{array}$ & -60089 & 58563 & 191366 & 251454 \\
\hline $\begin{array}{l}\text { Sales volume, tons \& Sprat (raw } \\
\text { material) expense, EUR }\end{array}$ & $\begin{array}{l}18.34 \& \\
540\end{array}$ & $\begin{array}{l}20.18 \& \\
450\end{array}$ & $\begin{array}{l}22.20 \& \\
405\end{array}$ & -61825 & 58563 & 179843 & 241668 \\
\hline $\begin{array}{l}\text { Proportion Anchovies to Pasta, \% } \\
\& \text { Labor costs, EUR }\end{array}$ & $\begin{array}{c}35 \% \& \\
7.2\end{array}$ & $\begin{array}{l}45 \% \& \\
\quad 6\end{array}$ & $\begin{array}{c}55 \% \& \\
4.8\end{array}$ & -56357 & 58563 & 183277 & 239635 \\
\hline $\begin{array}{l}\text { Proportion Anchovies to Pasta, } \% \\
\text { \& Anchovy pasta, sales price, } \\
\text { EUR }\end{array}$ & $\begin{array}{c}35 \% \& \\
7142.857\end{array}$ & $\begin{array}{c}45 \% \& \\
7500\end{array}$ & $\begin{array}{c}55 \% \& \\
7875\end{array}$ & -65035 & 58563 & 170348 & 235383 \\
\hline $\begin{array}{l}\text { Proportion Anchovies to Pasta, \% } \\
\& \text { Olive oil expense, EUR }\end{array}$ & $\begin{array}{c}35 \% \& \\
3450\end{array}$ & $\begin{array}{c}45 \% \& \\
3000\end{array}$ & $\begin{array}{c}55 \% \& \\
2550\end{array}$ & -41171 & 58563 & 165230 & 206401 \\
\hline $\begin{array}{l}\text { Anchovies in oil, sales price, EUR } \\
\& \text { Labor costs, EUR }\end{array}$ & $\begin{array}{l}14285.71 \\
\& 7.2\end{array}$ & $\begin{array}{l}15000 \\
\& 6\end{array}$ & $\begin{array}{l}15750 \\
\& 4.8\end{array}$ & -40809 & 58563 & 160929 & 201737 \\
\hline $\begin{array}{l}\text { Anchovies in oil, sales price, EUR } \\
\text { \& Anchovy pasta, sales price, } \\
\text { EUR }\end{array}$ & $\begin{array}{c}14285.71 \\
\& \\
7142.857\end{array}$ & $\begin{array}{l}15000 \\
\& 7500\end{array}$ & $\begin{array}{l}15750 \\
\& 7875\end{array}$ & -37934 & 58563 & 159885 & 197819 \\
\hline
\end{tabular}




\begin{tabular}{|c|c|c|c|c|c|c|c|}
\hline $\begin{array}{l}\text { Proportion Anchovies to Pasta, } \\
\text { EUR \& Sprat (raw material) } \\
\text { expense, EUR }\end{array}$ & $\begin{array}{c}35 \% \& \\
540\end{array}$ & $\begin{array}{c}45 \% \& \\
450\end{array}$ & $\begin{array}{c}55 \% \& \\
405\end{array}$ & -45563 & 58563 & 151781 & 197344 \\
\hline $\begin{array}{l}\text { Anchovies in oil, sales price, EUR } \\
\& \text { Olive oil expense, EUR }\end{array}$ & $\begin{array}{l}14285.71 \\
\& 3450\end{array}$ & $\begin{array}{l}15000 \\
\& 3000\end{array}$ & $\begin{array}{l}15750 \\
\& 2550\end{array}$ & -24192 & 58563 & 144312 & 168504 \\
\hline $\begin{array}{l}\text { Anchovies in oil, sales price, EUR } \\
\& \text { Sprat (raw material) expense, } \\
\text { EUR }\end{array}$ & $\begin{array}{l}14285.71 \\
\& 540\end{array}$ & $\begin{array}{l}15000 \\
\& 450\end{array}$ & $\begin{array}{l}15750 \\
\& 405\end{array}$ & -26102 & 58563 & 133837 & 159939 \\
\hline $\begin{array}{l}\text { Anchovy pasta, sales price, EUR } \\
\& \text { Labor costs, EUR }\end{array}$ & $\begin{array}{c}7142.857 \\
\& 7.2\end{array}$ & $\begin{array}{c}7500 \& \\
6\end{array}$ & $\begin{array}{c}7875 \& \\
4.8\end{array}$ & -17516 & 58563 & 136472 & 153988 \\
\hline $\begin{array}{l}\text { Olive oil expense, EUR \& Labor } \\
\text { costs EUR }\end{array}$ & $\begin{array}{c}3450 \& \\
7.2\end{array}$ & $\begin{array}{c}3000 \& \\
6\end{array}$ & $\begin{array}{c}2550 \& \\
4.8\end{array}$ & -3774 & 58563 & 120900 & 124673 \\
\hline $\begin{array}{l}\text { Anchovy pasta, sales price, EUR } \\
\& \text { Olive oil expense, EUR }\end{array}$ & $\begin{array}{l}7142.857 \\
\& 3450\end{array}$ & $\begin{array}{c}7500 \& \\
3000\end{array}$ & $\begin{array}{c}7875 \& \\
2550\end{array}$ & -899 & 58563 & 119855 & 120755 \\
\hline $\begin{array}{l}\text { Sprat (raw material) expense EUR } \\
\& \text { Labor costs, EUR }\end{array}$ & $540 \& 7.2$ & $450 \& 6$ & $\begin{array}{c}405 \& \\
4.8\end{array}$ & -5684 & 58563 & 110425 & 116108 \\
\hline $\begin{array}{l}\text { Anchovy pasta, sales price, EUR } \\
\& \text { Sprat (raw material) expense, } \\
\text { EUR }\end{array}$ & $\begin{array}{l}7142.857 \\
\& 540\end{array}$ & $\begin{array}{c}7500 \& \\
450\end{array}$ & $\begin{array}{c}7875 \& \\
405\end{array}$ & -2809 & 58563 & 109380 & 112190 \\
\hline $\begin{array}{l}\text { Sprat (raw material) expense, EUR } \\
\& \text { Olive oil expense, EUR }\end{array}$ & $\begin{array}{c}540 \& \\
3450\end{array}$ & $\begin{array}{c}450 \& \\
3000\end{array}$ & $\begin{array}{c}405 \& \\
2550\end{array}$ & 10933 & 58563 & 93808 & 82875 \\
\hline
\end{tabular}

Source: authors calculations.

Table 5 demonstrates the most critical changes in market parameters (group 1) compared to the remaining parameters (group 2), which is consistent with theoretical findings.

Summary results of sensitivity analysis is shown in Table 6.

Finally, this approach allows to understand the fact that there is a large number of possible developments of a situation in which the project will lose in attractiveness for the investor (NPV is less than zero) (Table 7).

\section{Fuzzy numbers}

Taking into account the static financial model of the project, and the NPV calculated on its basis, as well as the possible average cumulative deviation of the project parameters of $20 \%(+/-5 \%)$, determined by experts in modeling the sensitivity analysis, this

\section{Summary of Sensitivity Analysis, EUR}

Table 6

\begin{tabular}{|l|c|c|}
\hline Sensitivity analysis & NPV low extreme & NPV high extreme \\
\hline Local & -39306 & 166219 \\
\hline Pairwise local & -112343 & 254594 \\
\hline Global & -264707 & 465670 \\
\hline
\end{tabular}




\section{Sensitivity Chart Data}

\begin{tabular}{|l|l|l|l|l|l|l|l|l|l|l|}
\hline \multirow{2}{*}{ Indicator } & \multicolumn{3}{|c|}{$\begin{array}{c}\text { Corresponding input } \\
\text { value }\end{array}$} & \multicolumn{3}{|c|}{$\begin{array}{c}\text { Input value as \% of } \\
\text { base }\end{array}$} & \multicolumn{3}{c|}{ NPV output value, EUR } \\
\hline Input Variable & $\begin{array}{l}\text { Low } \\
\text { Output }\end{array}$ & $\begin{array}{l}\text { Base } \\
\text { Case }\end{array}$ & $\begin{array}{l}\text { High } \\
\text { Output }\end{array}$ & Low & Base & High & Low & Base & High & Swing \\
\hline Sales volume, tons & 18.35 & 20.18 & 22.20 & 0.91 & 1.00 & 1.10 & -39306 & 58562 & 166219 & 205526 \\
\hline $\begin{array}{l}\text { Proportion Anchovies } \\
\text { to Pasta, \% }\end{array}$ & 0.35 & 0.45 & 0.55 & 0.78 & 1.00 & 1.22 & -21777 & 58562 & 138903 & 160681 \\
\hline $\begin{array}{l}\text { Anchovies in oil, sales } \\
\text { price, EUR per ton }\end{array}$ & 14285 & 15000 & 15750 & 0.95 & 1.00 & 1.05 & -1331 & 58562 & 121452 & 122784 \\
\hline $\begin{array}{l}\text { Labor costs, EUR per } \\
\text { hour }\end{array}$ & 7.20 & 6.00 & 4.80 & 1.20 & 1.00 & 0.80 & 19086 & 58562 & 98039 & 78953 \\
\hline $\begin{array}{l}\text { Anchovy pasta, sales } \\
\text { price, EUR per ton }\end{array}$ & 7142 & 7500 & 7875 & 0.95 & 1.00 & 1.05 & 21960 & 58562 & 96995 & 75034 \\
\hline $\begin{array}{l}\text { Olive oil expense, EUR } \\
\text { per ton }\end{array}$ & 3450 & 3000 & 2550 & 1.15 & 1.00 & 0.85 & 35702 & 58562 & 81422 & 45720 \\
\hline $\begin{array}{l}\text { Sprat (raw material) } \\
\text { expense, EUR per ton }\end{array}$ & 540 & 450 & 405 & 1.20 & 1.00 & 0.90 & 33792 & 58562 & 70947 & 37154 \\
\hline
\end{tabular}

Source: authors calculations.

Table 8

Fuzzy Parameters

\begin{tabular}{|l|c|c|c|}
\hline Parameters $\backslash$ fuzzy values & $-5 \%$ deviation & $0 \%$ deviation & $+5 \%$ deviation \\
\hline Fuzzy volatility, $\tilde{\rho}$ & 0.19 & 0.20 & 0.21 \\
\hline Fuzzy jumping factor $\tilde{u}$ & 1.143793 & 1.15191 & 1.160084 \\
\hline Fuzzy jumping factor $\tilde{d}$ & 0.862007 & 0.868123 & 0.874284 \\
\hline Pu1 & 0.614822 & 0.640892 & 0.667148 \\
\hline Pd1 & 0.332852 & 0.359108 & 0.385178 \\
\hline
\end{tabular}

Source: authors calculations.

study proposes the fuzzy binomial valuation approach to evaluate investment project. To do this, we calculate the possible deviations up and down, as well as the probabilities of these deviations (Table 8).

Based on these parameters, authors have constructed a binomial tree of possible project returns (Table 9). Authors see that with some combinations of parameters (for example, with a constant annual change down, within limits proposed by experts), the discounted amount of income for the corresponding period becomes lower than the necessary investment in the project (also discounted for the corresponding period). This goes in line with the results obtained during the sensitivity analysis.

Naturally, this information makes the investor think about reducing risk and increasing the value of the project. Such approach allows to evaluate the kind of value of the option, to:

1. Allow time to reduce the risks of deviation of parameters in accordance with theoretical predictions, as well as focusing on specific risks with the greatest impact on the deviation of NPV, determined in the 
framework of a 2-stage sensitivity analysis.

2. Postpone the principal investment for the time necessary to reduce risks (Table 10).

3. Choose to implement a project, only if, because of the refinement of the parameters, it will be possible to reject implementation of the project if the specified parameters turn out to be too low to bring the project to a positive NPV.

Table 9

Binomial Tree of Values of the Project Cash Inflows, thousand EUR

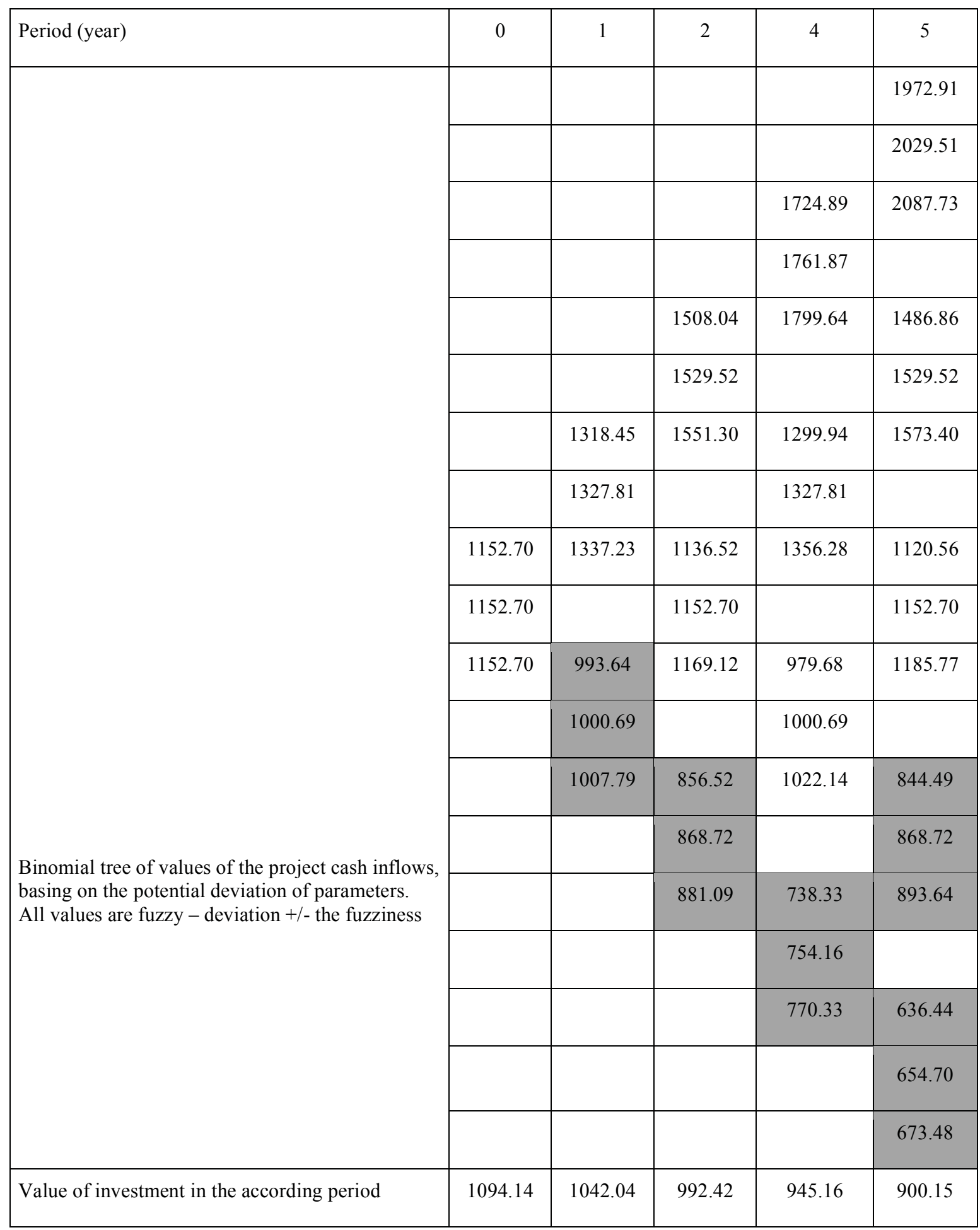

Source: authors calculations. 
In a specific example, authors choose to postpone the decision on investment in the project for 2 periods. In this case, the financial flow will remain the same but shifted to the right, which will reduce its NPV in today's money from 58563 EUR to 53118 EUR given the depreciating time value of money. Authors will make sure that the estimation of the FNPV with the binomial method is almost completely consistent with the usual NPV (Table 10).

Possible project potential outcomes due to parameter fluctuation can be either negative or positive with a slight difference which is explained by the shift of the FNPV pyramid to the right (Lambda $=0.55$ in our case). Below is the calculation of the FNPV of the deferred project, without the option to drop negative scenarios that shows FNPV similar to calculated NPV, that is 54695 EUR and 53118 EUR accordingly: where I2 is the investment deferred to period 2 and $\mathrm{V}$ is the according value from the Table 9 .

Now authors introduce the opportunity to postpone the investment decision and drop the project if the NPV is going to be negative after the year 2. Authors calculate the FNPV. Due to the fact that now only positive scenarios remain, the FNVP has grown to EUR values $(93.84,109.23,126.33)$. We calculate the mean value, and we get the FNPV of the deferred project with the ability to refuse investments after 2 years in the amount of 110.087 . This means that the "option" to "postpone and possibly drop project after 2 periods" could cost the FNPV - NPV $=56.968$ thousand euros.

\section{Conclusions}

The main findings of the study:

1. To succeed, companies must take risks to launch new products speedily and successfully. There is a

The Decision Tree without the Option to Abandon, thousand EUR

Table 10

\begin{tabular}{|c|c|c|c|}
\hline Fuzzy value at a period $\backslash$ No of period & 2 & 1 & 0 \\
\hline \multirow{7}{*}{ Each of the fuzzy options calculated as: } & 273.70 & & \\
\hline & 293.18 & & \\
\hline & 312.94 & 140.20 & \\
\hline & & 162.32 & \\
\hline & -63.29 & 186.47 & 38.47 \\
\hline & -48.60 & & 53.12 \\
\hline & -33.71 & -137.63 & 70.93 \\
\hline \multirow{4}{*}{$\begin{array}{l}\max \left(\tilde{u}^{2} V-I_{2}, 0\right) \\
\max \left(\tilde{u} \tilde{d} V-I_{2}, 0\right) \\
\max \left(\tilde{d^{2} V}-I_{2}, 0\right)\end{array}$} & & -134.38 & \\
\hline & -317.25 & -129.62 & \\
\hline & -306.18 & & \\
\hline & -294.96 & & \\
\hline & & $\lambda=$ & 0.55 \\
\hline & & $\mathrm{FNPV}=$ & 54.70 \\
\hline
\end{tabular}

Source: authors calculations. 
The Decision Tree with the Option to Abandon, thousand EUR

\begin{tabular}{|c|c|c|c|}
\hline Fuzzy value at a period $\backslash$ No of period & 2 & 1 & 0 \\
\hline \multirow{13}{*}{ Each of the fuzzy options calculated as: } & 273.70 & & \\
\hline & 293.18 & & \\
\hline & 312.94 & 160.26 & \\
\hline & & 178.95 & \\
\hline & 0.00 & 198.83 & 93.84 \\
\hline & 0.00 & & 109.23 \\
\hline & 0.00 & 0.00 & 126.33 \\
\hline & & 0.00 & \\
\hline & 0.00 & 0.00 & \\
\hline & 0.00 & & \\
\hline & 0.00 & & \\
\hline & & $\lambda=$ & 0.53 \\
\hline & & $\mathrm{FNPV}=$ & 110.09 \\
\hline
\end{tabular}

Source: authors calculations.

need to take strategic action to mitigate and avoid risks through risk management when developing new products. It is therefore vital to have the ability to identify and assess risk in the NPD process.

2. NPV is one of the most common ways to evaluate projects in terms of attractiveness to investors. Nevertheless, it does not help to make decisions on the implementation of projects with a high degree of uncertainty. Such are often the new product development projects. This is mainly because a static NPV does not consider the large possible deviations of the parameters in time.

3. The sensitivity analysis of the project gives a more complete picture of the risks and their impact on potential NPV. Such an analysis is also based on the assumptions; however, it introduces the concept of (still subjective) risk in assessing the possible outcomes of the project. In the framework proposed by this research, initial stage of risk management process could be carried out through risk identification. The sensitivity analysis performed according to the proposed framework shows the scale of the influence of certain factors (or their pairwise combinations) on the project result. Obviously, factors having the greatest impact on the change of NPV should be analyzed first.

4. Introducing the concept of FNPV (fuzzified NPV), applying the valuation of fuzzy sets and options in a binomial way, we offer a mathematical justification for the positive impact of parameter 
refinement on the investment project. The additional value from the project for the investor is generated by the reduction of risk, as well as by the possibility of dropping the project if the clarification of parameters does not lead to a positive result.

5. From a practical point of view, the actions to reduce risks can be various, starting from the conclusion of long-term contracts to testing of specific hypotheses of acceptance of goods by the market through the production of test batches in the so-called pilot plants, etc. We leave out of this study the in-depth review of possible risk reduction measures; nonetheless, the study suggests that financial limits for such measure implementation is determined by the price of the option to defer decision-making on investment in the project.

6. The developed framework for evaluating new product development projects by potential investors is quite simple in terms of the necessary computations for its implementation. It allows to bring up the risks of a new food product development projects, and make a more informed decision about the investment in such projects.

\section{References}

Ahuja, G. (2000). Collaboration Networks, Structural Holes, and Innovation: A Longitudinal Study. Administrative Science Quarterly, 45 (3): 425-55. https://doi.org/10.2307/2667105.

Anderson, Ph., Tushman, M.L. (2001). Organizational Environments and Industry Exit: The Effects of Uncertainty, Munificence and Complexity. Industrial and Corporate Change, 10 (3): 675711. https://doi.org/10.1093/icc/10.3.675.

Borgonovo, E., Peccati, L. (2004). Sensitivity Analysis in Investment Project Evaluation. International Journal of Production Economics, 90 (1): 17-25.

Borgonovo, E., Peccati, L. (2006). Uncertainty and Global Sensitivity Analysis in the Evaluation of Investment Projects. International Journal of Production Economics, Strategic Issues and Innovation in Production Economics, 104 (1): 62-73. https://doi.org/10.1016/j.ijpe.2005.05.024.

Carlsson, Ch., Fullér, R., Heikkilä, M., Majlender, P. (2007). "A Fuzzy Approach to R\&D Project Portfolio Selection." International Journal of Approximate Reasoning, Fuzzy Decision-Making Applications, 44 (2): 93-105. https://doi.org/ 10.1016/j.ijar.2006.07.003.

Cooper, R.G., Kleinschmidt, E.J. (1995). Benchmarking the Firm's Critical Success Factors in New Product Development. Journal of Product Innovation Management, 12 (5): 374-91. https://doi.org/10.1016/0737-6782(95)00059-3.
Cox, J.C., Ross, S.A., Rubinstein, M. (1979). Option Pricing: A Simplified Approach. Journal of Financial Economics, 7 (3): 229-63. https://doi.org/ 10.1016/0304-405X(79)90015-1.

Dodgson, M., Rothwell, R. (1991). External Linkages and Innovation in Small and Medium-Sized Enterprises. SSRN Scholarly Paper, ID 1506762. Rochester, NY: Social Science Research Network. https://papers.ssrn.com/abstract=1506762.

Freeman, Ch., Soete, L. (1997). The Economics of Industrial Innovation - 3rd Edition. Third edition edition. Cambridge, Mass: The M.I.T. Press.

Haahtela, T.J. (2010). Regression Sensitivity Analysis for Cash Flow Simulation Based Real Option Valuation. Procedia - Social and Behavioral Sciences, Sixth International Conference on Sensitivity Analysis of Model Output, 2 (6): 7670-71. https://doi.org/10.1016/j.sbspro. 2010.05.171.

Haaker, M.P.R., Verheijen P.J.T. (2004). Local and Global Sensitivity Analysis for a Reactor Design with Parameter Uncertainty. Chemical Engineering Research and Design, 82 (5): 591-98. https:// doi.org/10.1205/026387604323142630.

Ho, Sh.H., Liao, Sh.H. (2011). A Fuzzy Real Option Approach for Investment Project Valuation. Expert Syst. Appl., 38: 15296-302. https://doi.org/ 10.1016/j.eswa.2011.06.010.

Jerrard, R., Hands, D. eds. (2007). Design Management: Exploring Fieldwork and Applications. 1 edition. London; New York, NY: Routledge.

Jovanović, P. (1999). Application of Sensitivity Analysis in Investment Project Evaluation under Uncertainty and Risk. International Journal of Project Management, 17 (4): 217-22. https://doi.org/ 10.1016/S0263-7863(98)00035-0.

Kahraman, C., Ruan, D., Tolga, E. (2002). Capital Budgeting Techniques Using Discounted Fuzzy versus Probabilistic Cash Flows. Information Sciences, 142 (1-4): 57-76. https://doi.org/ 10.1016/S0020-0255(02)00157-3.

Kahraman, C. (2008). Fuzzy Engineering Economics with Applications. Springer.

Keizera, J.A., Halman, J.I.M., Song, M. (2002). From Experience: Applying the Risk Diagnosing Methodology. Journal of Product Innovation Management, 19 (3): 213-32. https://doi.org/ 10.1016/S0737-6782(02)00138-8.

Kim, Y.J, Vonortas, N.S. (2014). Managing Risk in the Formative Years: Evidence from Young Enterprises in Europe. Technovation, Risk and Uncertainty Management in Technological Innovation, 34 (8): 454-65. https://doi.org/ 10.1016/j.technovation.2014.05.004.

Klingelhöfer, H.E. (2009). Investments in EOP- 
Technologies and Emissions Trading - Results from a Linear Programming Approach and Sensitivity Analysis. European Journal of Operational Research, 196 (1): 370-83. https:// doi.org/10.1016/j.ejor.2008.03.016.

Mansor, N., Yahaya, S., Okazaki, K. (2016). Risk Factors Affecting New Product Development (NPD) Performance In Small Medium Enterprises (SMES), International journal of recent research and applied studies, 27(1): 8. https:// www.arpapress.com/Volumes/Vol27Issue1/IJR RAS_27_1_03.pdf

Meyer, M.H., Roberts, E.B. (1986). New Product Strategy in Small Technology-Based Firms: A Pilot Study. Management Science, 32 (7): 806-21.

Milliken, F.J. (1987). Three Types of Perceived Uncertainty about the Environment: State, Effect, and Response Uncertainty. The Academy of Management Review, 12 (1): 133-43. https:// doi.org/10.2307/257999.

Moenaert, R.K., De Meyer, A., Souder W.E., Deschoolmeester, D. (1995). R D/Marketing Communication during the Fuzzy Front-End. IEEE Transactions on Engineering Management, 42 (3): 243-58. https://doi.org/10.1109/17.403743.

Moskowitz, H.R., Saguy, I. S., Straus, T. eds. (2009). An Integrated Approach to New Food Product Development. 0 ed. CRC Press. https://doi.org/ 10.1201/9781420065558.

Mu J., Peng G., MacLachlan D.L. (2009). Effect of Risk Management Strategy on NPD Performance. Technovation, 29 (3): 170-80. https://doi.org/ 10.1016/j.technovation.2008.07.006.

Muzzioli, S., Reynaerts, H. (2008). American Option Pricing with Imprecise Risk-Neutral Probabilities. International Journal of Approximate Reasoning, Special Section on Logical Approaches to Imprecise Probabilities and Special Section on Imprecise Probabilities in Finance and Economics, 49 (1): 140-47. https://doi.org/10.1016/j.ijar.2007.06.011.

Muzzioli, S., Torricelli, C. (2004). A Multiperiod Binomial Model for Pricing Options in a Vague World. Journal of Economic Dynamics and Control, Financial decision models in a dynamical setting, 28 (5): 861-87. https://doi.org/10.1016/ S0165-1889(03)00060-5.

Park, Y.H. (2010). A Study of Risk Management and Performance Measures on New Product Development. Asian Journal on Quality, 11 (1): 39-48. https://doi.org/10.1108/15982681011051813.

Perez-Villarreal, B., Pozo, R. (1992). Ripening of the Salted Anchovy (Engraulis Encrasicholus): Study the Sensory, Biochemical and Microbiological Aspects. Developments in Food Science. http:// agris.fao.org/agris-search/search.do?recordID=
US201301770474.

Sabovics, M., Mugurevics, A., Silovs, M., Dmitrijeva, O. (2019a). Development of Technology and Recepies of Baltic Anchovy in Oil Preserves (Salted Products) and Baltic Anchovies Paste from Sprattus Balticus as Analogous to Traditional Italian Canned Anchovies in Oil and Mechanization of Technological Processes for Their Production", project no. 17-00-F01101000003, Latvia University of Life Sciences and Technologies.

Sabovics, M., Pilvere, I., Muizniece-Brasava, S., Silovs, M., Dmitrijeva, O. (2019b). Baltic sprat (Sprattus sprattus balticus) as a raw material for developing "anchovy" analogue. In: $19^{\text {th }}$ International multidisciplinary scientific GeoConference SGEM 2019: conference proceedings, Albena, Bulgaria, 9-11 December, 2019/ Bulgarian Academy of Sciences Sofia, 2019. Vol.19, Issue 6.3: Micro and nano technologies. Advances in biotechnology. Green buildings technologies and materials. Green design and sustainable architecture; pp.43.-50. https://www.scopus.com/inward/record.uri?eid= 2- s2.0- 85092461894\&partnerID=40\&md5= 2862942d40932719fd7159140870beef ISBN 9786197408997.

Sari, I.D., Kuchta, D. (2012). Fuzzy Global Sensitivity Analysis of Fuzzy Net Present Value. Control and Cybernetics, Vol. 41, no. 2: 481-96.

Sheen, J.N. (2005). Fuzzy Evaluation of Cogeneration Alternatives in a Petrochemical Industry. Computers \& Mathematics with Applications, 49 (5): 741-55. https://doi.org/10.1016/ j.camwa. 2004.10.035.

Taylor, R.B., West, T.M. (1992). Development of a Spreadsheet-Based Capital Investment Model with Sensitivity Analysis. Computers and Industrial Engineering, 23 (1-4): 431-433. https://doi.org/ 10.1016/0360-8352(92)90153-B.

Van Groenendaal, W.J.H., Kleijnen, J.P.C. (2002). Deterministic versus Stochastic Sensitivity Analysis in Investment Problems: An Environmental Case Study. European Journal of Operational Research 141 (1): 8-20. https://doi.org/10.1016/S03772217(01)00236-3.

Yeo, K. T., Qiu, F. (2003). The Value of Management Flexibility - a Real Option Approach to Investment Evaluation. International Journal of Project Management, 21 (4): 243-50. https://doi.org/ 10.1016/S0263-7863(02)00025-X.

Zadeh, L. A. (1965). Fuzzy Sets. Information and Control, 8 (3): 338-53. https://doi.org/10.1016/ S0019-9958(65)90241-X. 


\section{Acknowledgement}

Data used in the study was partially obtained within the Latvia University of Life Sciences and Technologies project "Development of technology and recipes of Baltic anchovy in oil preserves (Salted Products) and Baltic anchovies paste from Sprattus Balticus as analogous to traditional Italian canned anchovies in oil and mechanization of technological processes for its production" no. 17-00-F01101-000003, article is prepared for publishing partially financed under the project Z29 "Strengthening of scientific capacity" from the Latvia University of Life Sciences and Technologies and project lzp-2020/2-0413 "Assessment of the Implementation of the Latvian Bioeconomy Strategy 2030 and Possible Solutions for Achieving the Goals Set (LIBRA-LV)". 